Case Report

\title{
Scedosporium prolificans Septic Arthritis and Osteomyelitis of the Hip Joints in an Immunocompetent Patient: A Case Report and Literature Review
}

\author{
Luca Daniele, Michael Le, Adam Franklin Parr, and Lochlin Mark Brown \\ Department of Orthopaedics, Gold Coast Health Service, Gold Coast University Hospital, 1 Hospital Blvd., \\ Southport, QLD 4215, Australia \\ Correspondence should be addressed to Michael Le; michael.93le@gmail.com
}

Received 11 November 2016; Accepted 22 December 2016; Published 10 January 2017

Academic Editor: Mark K. Lyons

Copyright (C) 2017 Luca Daniele et al. This is an open access article distributed under the Creative Commons Attribution License, which permits unrestricted use, distribution, and reproduction in any medium, provided the original work is properly cited.

\begin{abstract}
Scedosporium prolificans, also known as Scedosporium inflatum, is a fungus widespread in soil, sewage, and manure. This species is highly virulent and is an emerging opportunistic pathogen found in penetrating injuries in immunocompromised patients. Here we report on an immunocompetent patient with bilateral hip S. prolificans-associated osteomyelitis and septic arthritis caused by intentional penetrating trauma. The condition was refractory to initial antimicrobial suppression and surgical irrigation and debridement. Successful outcome was achieved after incorporating a bilateral two-stage total-hip-arthroplasty with Voriconazoleloaded cement and spacer.
\end{abstract}

\section{Introduction}

Scedosporium prolificans, also known as Scedosporium inflatum, is a fungus ubiquitous in soil, sewage, potted plants, and manure [1]. This species is an emerging opportunistic pathogen found in penetrating injuries in immunocompromised patients [2]. S. prolificans infections are resistant to most currently available antifungals thus making treatment options challenging [3]. It was first described in 1984 after isolation from a bone biopsy specimen in an area of osteomyelitis [4]. Treatment of S. prolificans infections is complicated by its resistance to most currently available antifungals [3]. Disseminated infections occur more commonly in immunocompromised individuals [5] while localized infections presenting as septic arthritis and osteomyelitis are more common in immunocompetent patients.

\section{Case Presentation}

A 47-year-old male with background history of bilateral hip osteoarthritis presented to the Emergency Department in February 2016 with a one-month history of progressive bilateral groin pain and four-day history of inability to bear weight on the left side. The pain was worse on the left and radiated towards the knees bilaterally. The patient was otherwise well and denied a history of fevers or other constitutional symptoms. Prior to presentation, he was privately managed for five months with multiple intra-articular hip HCLA injections by a radiologist. This provided good effect for four months until one month prior to presentation.

On examination, the patient had hyperaesthesia on palpation over the greater trochanter and groin region. Passive and active movement of both hips were painful with restricted ranges of motion in all directions bilaterally. Neurovascular status was intact. Initial laboratory results revealed a raised CRP (105) with unremarkable FBC, U\&E, and LFTs. Neurovascular status was intact. Initial laboratory results revealed a raised CRP (105) with unremarkable FBC, U\&E, and LFTs. 24-hour blood cultures, Chlamydia trachomatis, gonorrhoea, rheumatoid factor, and anticyclic citrullinated peptide in consideration of rheumatic and infective causes were negative.

Ultrasound guided aspiration of the left hip revealed haemoserous fluid and scant leukocytes but was negative for crystals and bacteria. Interim bone scan (Figure 1) and MRI (Figure 2) showed a probable focus of osteomyelitis within the left anterior inferior iliac spine (AIIS) and small bilateral 


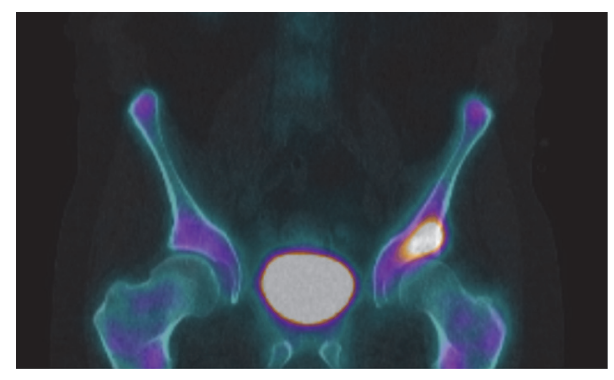

FIGURE 1: Delayed-phase SPECT/CT displaying increased activity in the left AIIS extending to the superior acetabular rim.

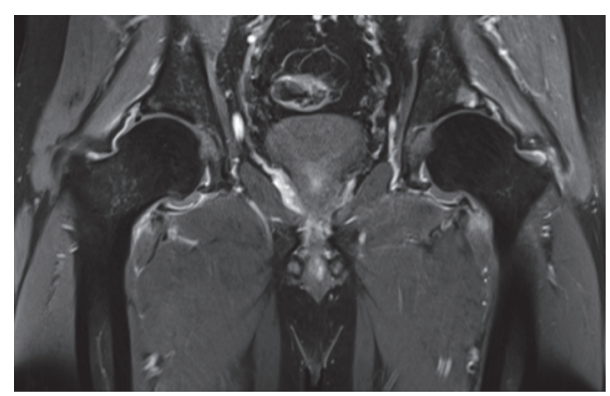

FIGURE 2: T2 weighted MRI demonstrating a hyperintense focus in the left superior acetabular rim and hip effusion and capsular edema consistent with osteomyelitis and septic arthritis.

effusions concerning for superimposed septic arthritis. Bone scintigraphy confirmed activity at the left AIIS (Figure 2). Despite being commenced on IV flucloxacillin, ciprofloxacin, and vancomycin, a low-grade fever developed over the following days. A left hip washout revealed cloudy fluid and exudate with reactive appearance of labrum and capsule. Cultures returned a positive result for S. prolificans after five days necessitating the commencement of Voriconazole and Terbinafine.

Following initial improvements, the patient developed worsening left groin pain and rising CRP. A second washout and MRI suggested ongoing left septic arthritis and associated osteomyelitis with contralateral concerning pathology in the right hip. A subsequent bilateral hip washout, left head core decompression, and acetabulum debridement were performed on day 28. Repeat MRI demonstrated worsening left septic arthritis and acetabular osteomyelitis despite ongoing surgical debridement, lavage, and medical therapy. All leftsided intraoperative samples returned positive for S. prolificans while right-sided specimens remained negative to date.

Departmental decision was made to perform a two-stage left total-hip-arthroplasty. The first stage initially involved aggressive acetabular debridement, lavage and reaming. An acetabular cup loaded with $200 \mathrm{mg}$ Voriconazole in Palacos cement and similarly loaded cement spacer were implanted (Figure 3). Prior to home discharge with regular Voriconazole, the patient was mobilising with pain score of 0 on the left and minimal pain on the right side. However, due to interval radiological changes (Figure 4) and right-sided pain at follow-up, a first-stage right hip arthroplasty was performed (Figure 5). The patient is currently seven months after left and 6 months after right first-stage total-hip-arthroplasty. Progression to second-stage total-hip-arthroplasty will be considered following a disease-free period of at least twelve months.

\section{Discussion}

Scedosporium prolificans, also known as Scedosporium inflatum, is an emerging opportunistic pathogen found in penetrating injuries in immunocompromised patients [2]. Treatment of $S$. prolificans infections is complicated by its resistance to most currently available antifungals [3]. Disseminated infections occur more commonly in immunocompromised individuals [5] while localized infections presenting as septic arthritis and osteomyelitis are more common in immunocompetent patients. We believe the repeated HCLA injections provided a point of entry and a locally immunedeficient environment for the infection to take hold. Corticosteroids may induce an immunosuppressed environment as they inhibit the accumulation of inflammatory cells, phagocytosis, and production of neutrophils and prevent the synthesis and secretion of inflammatory mediators $[6,7]$. Previous literature has suggested that the local immunosuppressive effects associated with invasive steroid treatments such as HCLA injection may influence and increase the susceptibility to infection [8]. Thus, any factors which could potentially inhibit the ability of joint to withstand infection should be minimized [8]. This is also in light of the possibility of infection being introduced at the time of invasive therapy. Several case reports of septic arthritis and/or osteomyelitis have appeared in published literature. Here we report on an immunocompetent patient with bilateral hip S. prolificans-associated osteomyelitis and septic arthritis treated with a two-stage total-hip-arthroplasty incorporating Voriconazole-loaded cement and spacer.

Although treatment is difficult, localized infections have previously showed response to antifungal therapy and surgical debridement. A recent systematic review included 23 reported cases of $S$. prolificans-associated osteoarticular infections in both immunocompetent or immunocompromised patients [9]. Our review of the English literature revealed 14 case reports of $S$. prolificans infection of the joints (Table 1) in only immunocompetent patients. Reports have seen success with older antifungal agents including Amphotericin B, Ketoconazole, Miconazole, nystatin, 5-fluorocytosine, and fluconazole $[3,10,11]$. Three previous reports have demonstrated satisfactory results with newer antifungal agents Terbinafine/Voriconazole in immunocompetent patients with septic arthritis [12-15]. Another report has shown success in an 8-year-old immunocompetent patient using Hexadecylphosphocholine with Voriconazole/Terbinafine [16]. In vitro synergistic effects have been reported with Voriconazole and Terbinafine, reducing the minimum inhibitory concentration for $S$. prolificans $[17,18]$. However, there remains no consensus for the duration of treatment with the Voriconazole/Terbinafine combination for septic arthritis and osteomyelitis caused by S. prolificans. Regardless of that, 


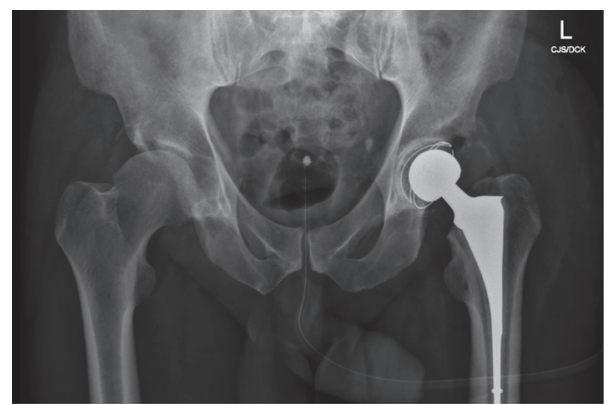

Figure 3: Postoperative radiograph demonstrating first-stage cemented total hip replacement with 48/32 mm Stryker RimFit Ace-tabular cup and size 9 Biomet Simplex cement spacer.

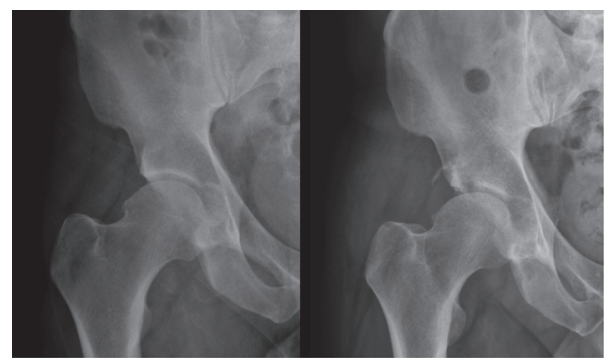

FIGURE 4: Plain radiograph showing progressive osteolysis of the superior right acetabular rim consistent with chronic infection.

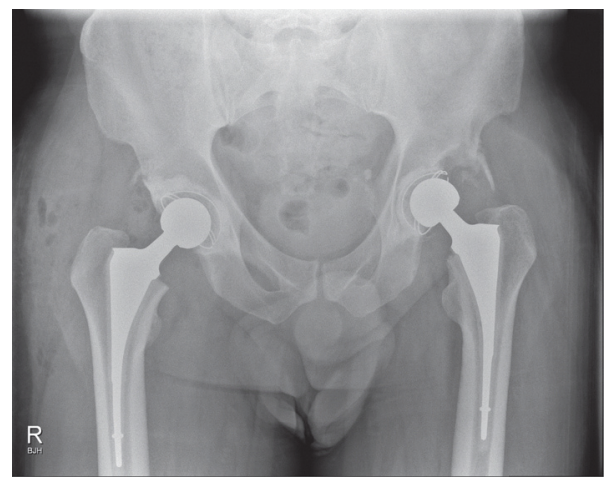

FIGURE 5: Postoperative radiograph demonstrating bilateral first-stage cemented total hip replacement.

irrigation and surgical debridement are vital components in the eradication of infections in all cases. In cases unresponsive to antifungal treatment and surgical debridement, arthrodesis [15] alongside radical excisions and amputations has been necessitated [19].

This is the first described case to our knowledge of S. prolificans-associated septic arthritis and osteomyelitis treated using a two-stage hip arthroplasty with Voriconazole-loaded cement and spacer. Studies have confirmed that Voriconazole is stable at high temperatures and therefore suitable to be used with Palacos cement [20]. Previous studies have suggested that the elution of Voriconazole from bone cement would be able to maintain a minimum inhibitory concentration for $S$. prolificans [21]. Higher antimicrobial content has been shown to increase cement porosity and thus elution. However, concern exists as load-bearing strength potential of cement and hardening time is consequently reduced. This affects the time required for spacer preparation. Therefore, a balance between these factors needs to be considered.

The objective in this case, to permanently eradicate the infection and restore function to the patient, was successful. This case therefore highlights the need to consider alternative avenues before undertaking more drastic measures such as arthrodesis or amputation for $S$. prolificans septic arthritis and osteomyelitis.

\section{Consent}

Informed consent was obtained from the patient for the publication of this case report. 
TABLE 1: Reported Scedosporium prolificans-associated osteomyelitis and/or septic arthritis infections from penetrating trauma in immunocompetent patients.

\begin{tabular}{|c|c|c|c|c|c|c|}
\hline Age/gender & Location & $\begin{array}{l}\text { Mechanism } \\
\text { of } \\
\text { introduction }\end{array}$ & Site/presentation & Treatments used & $\begin{array}{l}\text { Final } \\
\text { Outcome }\end{array}$ & Author/Year \\
\hline $6 / \mathrm{M}$ & $\begin{array}{l}\text { North } \\
\text { America }\end{array}$ & $\begin{array}{l}\text { Penetrating } \\
\text { injury }\end{array}$ & Foot osteomyelitis & $\begin{array}{c}\text { Surgical debridement, } \\
\text { Amphotericin B, } \\
\text { Ketoconazole, Miconazole, }\end{array}$ & Improvement & $\begin{array}{l}\text { Taj-Aldeen et } \\
\text { al. } 2015 \text { [9] }\end{array}$ \\
\hline $3 / \mathrm{M}$ & $\begin{array}{l}\text { South } \\
\text { America }\end{array}$ & Trauma & $\begin{array}{l}\text { Knee septic } \\
\text { arthritis }\end{array}$ & $\begin{array}{c}\text { Surgery, Ketoconazole, } \\
\text { Amphotericin B, } \\
\text { Ketoconazole, } \\
\text { intra-articular } \\
\text { Amphotericin B, } \\
\text { intra-articular Miconazole }\end{array}$ & Amputation & $\begin{array}{l}\text { Wilson et al. } \\
1990[19]\end{array}$ \\
\hline $5 / \mathrm{M}$ & $\begin{array}{l}\text { North } \\
\text { America }\end{array}$ & $\begin{array}{l}\text { Penetrating } \\
\text { trauma from } \\
\text { thorn }\end{array}$ & $\begin{array}{l}\text { Knee septic } \\
\text { arthritis }\end{array}$ & $\begin{array}{c}\text { Surgery, Amphotericin B } \\
\text { 5-FC, intra-articular } \\
\text { Amphotericin B, } \\
\text { Miconazole, Ketoconazole }\end{array}$ & Improvement & $\begin{array}{c}\text { Wilson et al. } \\
1990[19]\end{array}$ \\
\hline $54 / \mathrm{M}$ & $\begin{array}{l}\text { North } \\
\text { America }\end{array}$ & $\begin{array}{l}\text { Trauma } \\
\text { from axe }\end{array}$ & Knee arthritis & $\begin{array}{l}\text { Surgery, Amphotericin B, } \\
\text { Ketoconazole; Miconazole }\end{array}$ & Improvement & $\begin{array}{c}\text { Wilson et al. } \\
1990[19]\end{array}$ \\
\hline $6 / \mathrm{M}$ & $\begin{array}{l}\text { North } \\
\text { America }\end{array}$ & $\begin{array}{l}\text { Penetrating } \\
\text { injury from } \\
\text { nail }\end{array}$ & Foot osteomyelitis & Surgical debridement & Improvement & $\begin{array}{l}\text { Wilson et al. } \\
1990[19]\end{array}$ \\
\hline $6 / \mathrm{M}$ & $\begin{array}{l}\text { North } \\
\text { America }\end{array}$ & $\begin{array}{c}\text { Penetrating } \\
\text { injury from } \\
\text { nail }\end{array}$ & Foot osteomyelitis & $\begin{array}{l}\text { Surgery, Amphotericin B, } \\
\text { Ketoconazole }\end{array}$ & Improvement & $\begin{array}{l}\text { Wilson et al. } \\
1990 \text { [19] }\end{array}$ \\
\hline $35 / \mathrm{M}$ & $\begin{array}{l}\text { North } \\
\text { America }\end{array}$ & $\begin{array}{l}\text { Penetrating } \\
\text { injury/IV } \\
\text { drug use }\end{array}$ & Hip septic arthritis & $\begin{array}{l}\text { Joint drainage, } \\
\text { Amphotericin B, } \\
\text { 5-fluorocytosine }\end{array}$ & Improvement & $\begin{array}{l}\text { Wilson et al. } \\
1990 \text { [19] }\end{array}$ \\
\hline $11 / \mathrm{M}$ & Australia & Laceration & $\begin{array}{l}\text { Ankle septic } \\
\text { arthritis }\end{array}$ & $\begin{array}{c}\text { Surgical debridement, } \\
\text { Amphotericin B, } \\
\text { Itraconazole }\end{array}$ & Improvement & $\begin{array}{l}\text { Wood et al. } \\
1992[11]\end{array}$ \\
\hline $5 / \mathrm{M}$ & $\begin{array}{l}\text { North } \\
\text { America }\end{array}$ & $\begin{array}{l}\text { Penetrating } \\
\text { injury from } \\
\text { nail }\end{array}$ & Foot osteomyelitis & $\begin{array}{c}\text { Surgical debridement, } \\
\text { polyhexamethylene, } \\
\text { biguanide, Voriconazole, } \\
\text { caspofungin }\end{array}$ & Improvement & $\begin{array}{l}\text { Steinbach et } \\
\text { al. } 2003[3]\end{array}$ \\
\hline $9 / \mathrm{M}$ & Sweden & $\begin{array}{c}\text { Penetrating } \\
\text { injury from } \\
\text { thorn }\end{array}$ & Knee osteomyelitis & $\begin{array}{c}\text { Surgical debridement, } \\
\text { cefuroxime, Amphotericin } \\
\text { B, Itraconazole, } \\
\text { Voriconazole }\end{array}$ & $\begin{array}{l}\text { Improvement } \\
\text { with } \\
\text { arthrodesis }\end{array}$ & $\begin{array}{c}\text { Studahl et al. } \\
2003[15]\end{array}$ \\
\hline $5 / \mathrm{M}$ & Australia & $\begin{array}{l}\text { Ankle } \\
\text { abrasion due } \\
\text { to trauma }\end{array}$ & $\begin{array}{l}\text { Ankle septic } \\
\text { arthritis }\end{array}$ & $\begin{array}{c}\text { Surgical debridement, } \\
\text { Amphotericin B, } \\
\text { Itraconazole, Terbinafine, } \\
\text { Voriconazole }\end{array}$ & Improvement & $\begin{array}{l}\text { Dalton et al. } \\
2006[13]\end{array}$ \\
\hline $8 / \mathrm{F}$ & Australia & $\begin{array}{l}\text { Trauma } \\
\text { from tractor }\end{array}$ & $\begin{array}{l}\text { Hip osteomyelitis } \\
\text { and hip septic } \\
\text { arthritis }\end{array}$ & $\begin{array}{l}\text { Surgical debridement, } \\
\text { Hexadecylphosphocholine, } \\
\text { Terbinafine, Voriconazole }\end{array}$ & Improvement & $\begin{array}{c}\text { Kesson et al. } \\
2009[16]\end{array}$ \\
\hline $4 / \mathrm{M}$ & $\begin{array}{l}\text { United } \\
\text { Kingdom }\end{array}$ & $\begin{array}{c}\text { Penetrating } \\
\text { injury from } \\
\text { thorn }\end{array}$ & Foot osteomyelitis & $\begin{array}{l}\text { Surgical debridement, } \\
\text { Voriconazole, Terbinafine }\end{array}$ & Improvement & $\begin{array}{l}\text { Bhagavatula } \\
\text { et al. } 2014 \text { [14] }\end{array}$ \\
\hline $54 / \mathrm{M}$ & Australia & $\begin{array}{l}\text { Penetrating } \\
\text { injury from } \\
\text { HCLA } \\
\text { injections }\end{array}$ & $\begin{array}{l}\text { Hip osteomyelitis } \\
\text { and hip septic } \\
\text { arthritis }\end{array}$ & $\begin{array}{c}\text { 2-stage } \\
\text { total-hip-arthroplasty with } \\
\text { Voriconazole-loaded } \\
\text { cement and spacer, } \\
\text { Voriconazole, Terbinafine }\end{array}$ & Improvement & $\begin{array}{c}\text { Daniele et al. } \\
2016\end{array}$ \\
\hline
\end{tabular}




\section{Competing Interests}

The authors declare that there is no conflict of interests regarding the publication of this paper.

\section{References}

[1] K. J. Cortez, E. Roilides, F. Quiroz-Telles et al., "Infections caused by Scedosporiumspp.," Clinical Microbiology Reviews, vol. 21, no. 1, pp. 157-197, 2008.

[2] J. Meletiadis, J. W. Mouton, J. F. G. M. Meis, and P. E. Verweij, "Combination chemotherapy for the treatment of invasive infections by Scedosporium prolificans," Clinical Microbiology and Infection, vol. 6, no. 6, pp. 336-337, 2000.

[3] W. J. Steinbach, W. A. Schell, J. L. Miller, and J. R. Perfect, "Scedosporium prolificans osteomyelitis in an immunocompetent child treated with voriconazole and caspofungin, as well as locally applied polyhexamethylene biguanide," Journal of Clinical Microbiology, vol. 41, no. 8, pp. 3981-3985, 2003.

[4] D. Malloch and I. Salkin, A New Species of Scedosporium Associated with Osteomyelitis in Humans, Mycotaxon, 1984.

[5] B. P. Howden, M. A. Slavin, A. P. Schwarer, and A. M. Mijch, "Successful control of disseminated Scedosporium prolificans infection with a combination of voriconazole and terbinafine," European Journal of Clinical Microbiology and Infectious Diseases, vol. 22, no. 2, pp. 111-113, 2003.

[6] P. Creamer, "Intra-articular corticosteroid treatment in osteoarthritis," Current Opinion in Rheumatology, vol. 11, no. 5, pp. 417-421, 1999.

[7] E. Ayhan, H. Kesmezacar, and I. Akgun, "Intraarticular injections (corticosteroid, hyaluronic acid, platelet rich plasma) for the knee osteoarthritis," World Journal of Orthopaedics, vol. 5, no. 3, pp. 351-361, 2014.

[8] S. Kaspar and J. D. V. de Beer, "Infection in hip arthroplasty after previous injection of steroid," Journal of Bone and Joint Surgery-Series B, vol. 87, no. 4, pp. 454-457, 2005.

[9] S. J. Taj-Aldeen, B. Rammaert, M. Gamaletsou et al., "Osteoarticular infections caused by non-Aspergillus filamentous fungi in adult and pediatric patients: a systematic review," Medicine, vol. 94, no. 50, Article ID e2078, 2015.

[10] M. Malekzadeh, G. D. Overturf, S. B. Auerbach, L. Wong, and M. Hirsch, "Chronic, recurrent osteomyelitis caused by Scedosporium inflatum," The Pediatric Infectious Disease Journal, vol. 9, no. 5, pp. 357-359, 1990.

[11] G. M. Wood, J. G. McCormack, D. B. Muir et al., "Clinical features of human infection with scedosporium inflatum," Clinical Infectious Diseases, vol. 14, no. 5, pp. 1027-1033, 1992.

[12] I. B. Gosbell, V. Toumasatos, J. Yong, R. S. Kuo, D. H. Ellis, and R. C. Perrie, "Cure of orthopaedic infection with Scedosporium prolificans, using voriconazole plus terbinafine, without the need for radical surgery," Mycoses, vol. 46, no. 5-6, pp. 233-236, 2003.

[13] P. A. Dalton, W. J. Munckhof, and D. W. Walters, "Scedosporium prolificans: an uncommon cause of septic arthritis," ANZ Journal of Surgery, vol. 76, no. 7, pp. 661-663, 2006.

[14] S. Bhagavatula, L. Vale, J. Evans, C. Carpenter, and R. A. Barnes, "Scedosporium prolificans osteomyelitis following penetrating injury: a case report," Medical Mycology Case Reports, vol. 4, no. 1, pp. 26-29, 2014.

[15] M. Studahl, T. Backteman, F. Stålhammar, E. Chryssanthou, and B. Petrini, "Bone and joint infection after traumatic implantation of Scedosporium prolificans treated with voriconazole and surgery," Acta Paediatrica, International Journal of Paediatrics, vol. 92, no. 8, pp. 980-982, 2003.

[16] A. M. Kesson, M. C. Bellemore, T. J. O’Mara, D. H. Ellis, and T. C. Sorrell, "Scedosporium prolificans osteomyelitis in an immunocompetent child treated with a novel agent, hexadecylphospocholine (miltefosine), in combination with terbinafine and voriconazole: a case report," Clinical Infectious Diseases, vol. 48, no. 9, pp. 1257-1261, 2009.

[17] "In vitro synergy between terbinafine and voriconazole against Scedosporium prolificans," in Proceedings of the 42nd Interscience Conference on Antimicrobial Agents and Chemotherapy, R. Perrie and D. Ellis, Eds., San Diego, Calif, USA, 2002.

[18] J. Meletiadis, J. F. G. M. Meis, J. W. Mouton et al., "In vitro activities of new and conventional antifungal agents against clinical Scedosporium isolates," Antimicrobial Agents and Chemotherapy, vol. 46, no. 1, pp. 62-68, 2002.

[19] C. M. Wilson, E. J. O’Rourke, M. R. McGinnis, and I. F. Salkin, "Scedosporium inflatum: clinical spectrum of a newly recognized pathogen," Journal of Infectious Diseases, vol. 161, no. 1, pp. 102-107, 1990.

[20] J. J. Deelstra, D. Neut, and P. C. Jutte, “Successful treatment of Candida albicans-infected total hip prosthesis with staged procedure using an antifungal-loaded cement spacer," Journal of Arthroplasty, vol. 28, no. 2, pp. 374.e5-374.e8, 2013.

[21] C. Grimsrud, R. Raven, A. W. Fothergill, and H. T. Kim, “The in vitro elution characteristics of antifungal-loaded PMMA bone cement and calcium sulfate bone substitute," Orthopedics, vol. 34, no. 8, pp. e378-e381, 2011. 


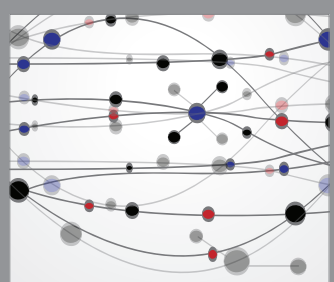

The Scientific World Journal
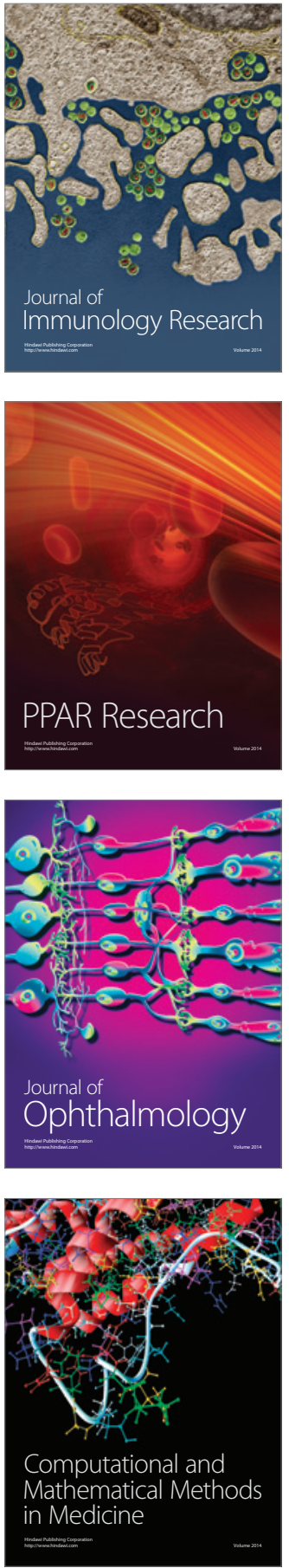

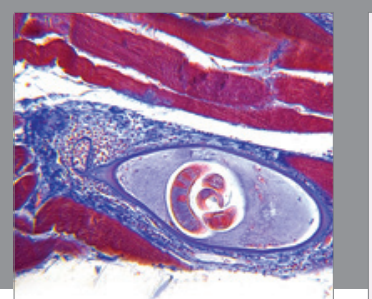

Gastroenterology Research and Practice
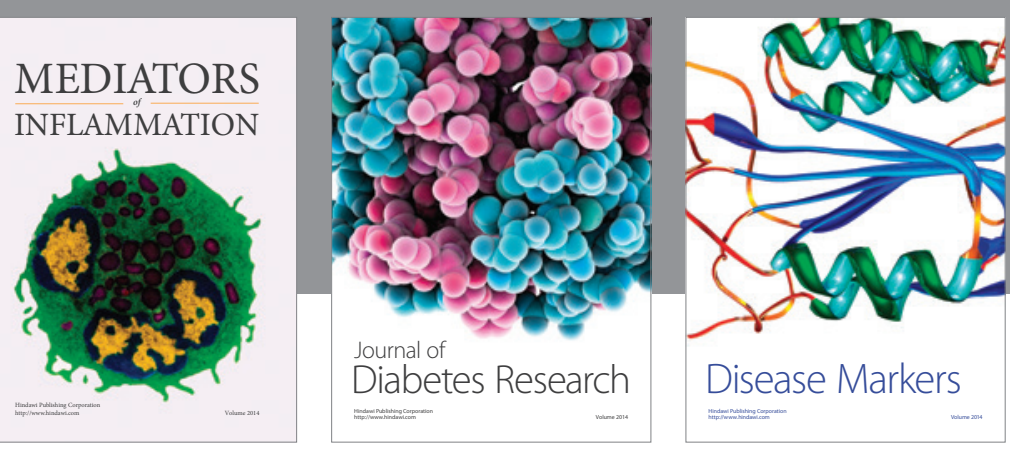

Disease Markers

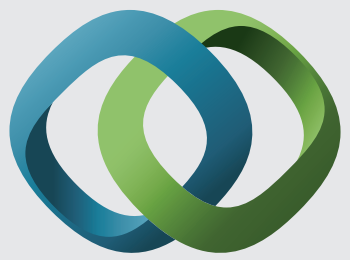

\section{Hindawi}

Submit your manuscripts at

https://www.hindawi.com
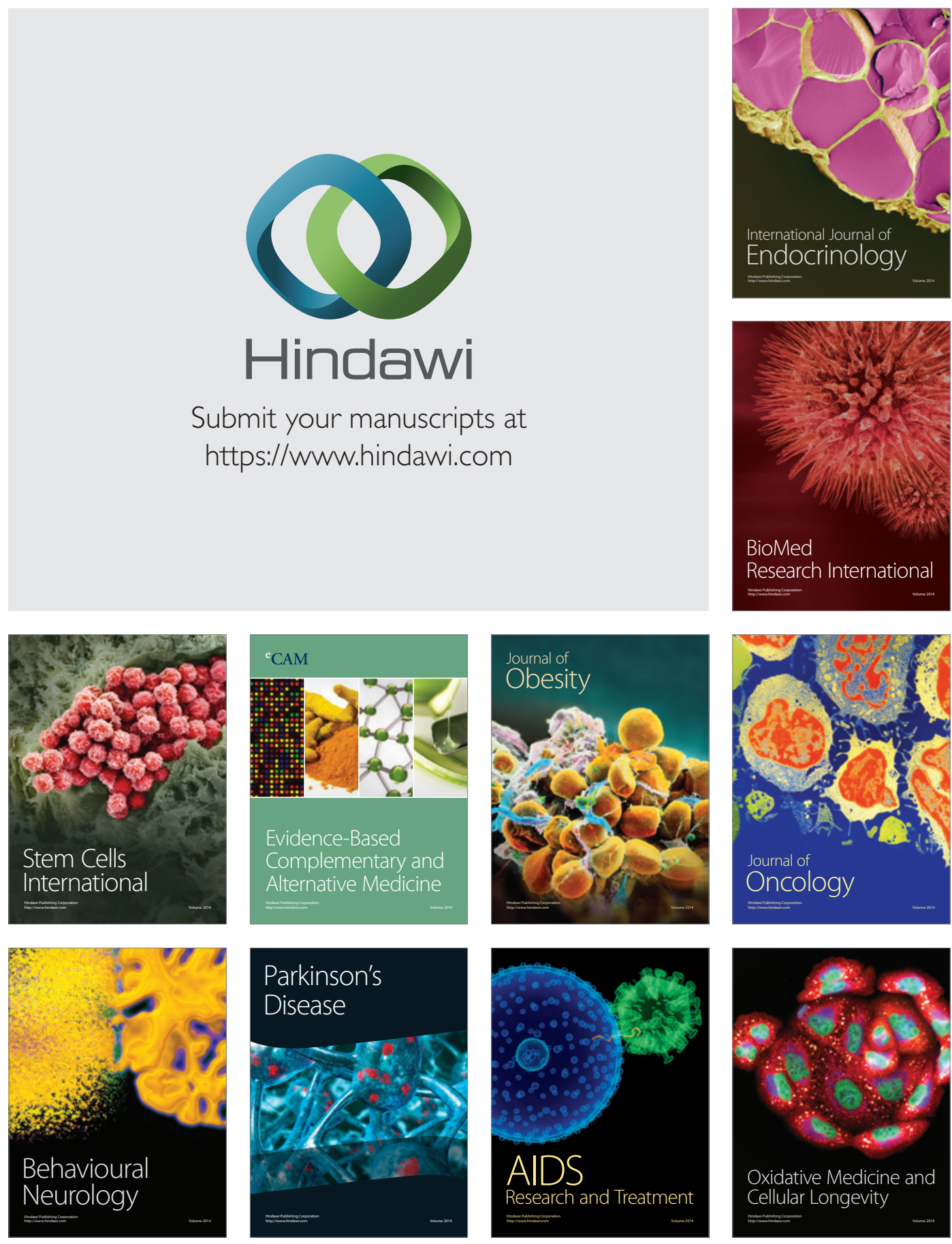